\title{
気圧変動に伴う長周期波発生過程の数值解析
}

\section{A Numerical Study on Long-Wave Generation due to Air-Pressure Change}

\author{
柿沼太郎 $^{1} \cdot$ 井上太介 $^{2} \cdot$ 日高壮一郎 ${ }^{3} \cdot$ 浅野敏之 $^{4} \cdot$ 柊田幸助 $^{5}$ \\ Taro KAKINUMA, Taisuke INOUE, Souichiro HIDAKA, Toshiyuki ASANO and Kousuke FUKITA
}

\begin{abstract}
The generation of long waves due to air-pressure change was numerically simulated in model basins of uniform water depth, as well as East Chine Sea, where the location of air-pressure change moved in the eastern direction, using a nonlinear shallow-water model. Long waves of large wave height require larger change rate of air pressure. If the moving velocity of the location of air-pressure change is larger than the celerity of shallow-water waves, the wave height of generated long waves is not so large, while the wavelength becomes longer. The long-wave train increases the wave height near Kamikoshiki Island. The air-pressure change was simply assumed according to the air-pressure data actually observed on an island, resulting in a long-wave period close to that of the oscillation mode in Urauchi Bay, Kamikoshiki Island.
\end{abstract}

\section{1. 序論}

2009年2月 24 日〜 26日に, 九州地方の広範囲で湾水振 動を伴う比較的大きな潮位変動が発生し, 鹿児島県上㥢 （かみこしき）島浦内湾湾奥の小島漁港では，船舶の転 覆, 家屋の床下浸水や堤防の破損が生じた（柿沼ら, 2009)。このような被害を未然に防ぐためには，各湾に おいて発生する長周期波の特性を把握し, 港の設計や, 各種施設の設置時に考慮しておくことが要求される.

こうした湾水振動は, 外洋より伝播した波列が湾内に 入射し，ある周期の長周期波成分が湾内で選択的に増幅 されることによって発生する。ところで, 湾水振動が生 じるような周期の長周期波が湾に入射しても，その継続 時間が短ければ，湾水振動は，高潮位を示すほど発達す ることなく減衰するであろう。すなわち，現地の湾で顕 著な湾水振動が発生したとき，湾の固有周期に近い長周 期波が，十分な数の波からなる波列として湾に入射した と考えられる，湾内の大きな振動は，入射波の周期，振 幅，そして，継続時間に依存して発生するのである.

ところで，長周期波が外洋より入射する原因の一つと して, 外洋に扔ける海上の微気圧変動に伴う長周期波の 発生が考えられている（Hibiya・Kajiura，1982）。この 微気圧変動は, 低気圧や前線の移動等によって生じ得る.

そこで, 本研究では, 九州西岸域の湾に扔ける湾水振 動が, 外洋上に打ける気圧変動域の移動に伴う長周期波

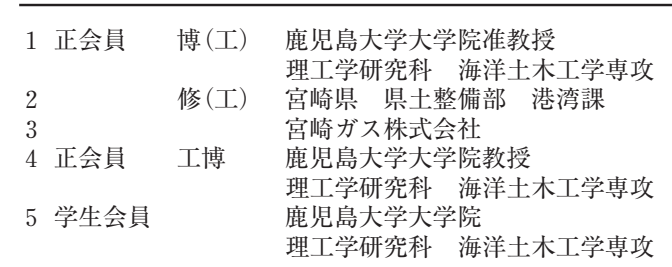

の入射によって発生すると仮定する，そして，気圧変動 域の移動に伴う長周期波発生過程の数值解析を行ない, 上甑島浦内湾内に高い増幅率が現れるような周期の長周 期波が東シナ海で発生し得るのかに関して検討する.

\section{2. 基礎方程式系と数值解析法}

基礎方程式系は，式（1）～（3）に示す，連続方程式及 び海面上の気圧勾配を考慮した非線形浅水方程式である.

$$
\begin{gathered}
\frac{\partial \eta}{\partial t}+\frac{\partial}{\partial x}[(h+\eta) U]+\frac{\partial}{\partial y}[(h+\eta) V]=0 \cdots \cdots(1) \\
\frac{\partial U}{\partial t}+\frac{\partial U^{2}}{\partial x}+\frac{\partial U V}{\partial y}=f V-g \frac{\partial \eta}{\partial x}-\frac{1}{\rho} \frac{\partial p}{\partial x} \\
+A_{h}\left(\frac{\partial^{2} U}{\partial x^{2}}+\frac{\partial^{2} U}{\partial y^{2}}\right)-\frac{K U \sqrt{U^{2}+V^{2}}}{\eta+h} \\
\frac{\partial V}{\partial t}+\frac{\partial U V}{\partial x}+\frac{\partial V^{2}}{\partial y}=-f U-g \frac{\partial \eta}{\partial y}-\frac{1}{\rho} \frac{\partial p}{\partial y} \\
+A_{h}\left(\frac{\partial^{2} V}{\partial x^{2}}+\frac{\partial^{2} V}{\partial y^{2}}\right)-\frac{K V \sqrt{U^{2}+V^{2}}}{\eta+h}
\end{gathered}
$$

ここで，U及び $V は ，$ 全水深にわたり一様と仮定した水 平方向流速, $h$ は, 静水深, $f$ は, Coriolis係数, $\eta$ は, 水 面変動, $g$ は, 重力加速度, $K$ は, 海底摩擦係数, $A_{h}$ は, 水平拡散係数, そして, $p$ は, 海面上の圧力である.

本研究では, 簡単のためにCoriolisの効果を無視して $f=0.0 \mathrm{~s}^{-1}$ とし, また, $g=9.8 \mathrm{~m} / \mathrm{s}^{2}$ とする. 水平拡散係数 $A_{h}$ の值に関しては, $A_{h}=3.0 \mathrm{~m}^{2} / \mathrm{s}$ 及び $100.0 \mathrm{~m}^{2} / \mathrm{s}$ の二通り に対してI型湾の波高増幅率に殆ど差が見られないこと を確認し, すべてのケースで $A_{h}=3.0 \mathrm{~m}^{2} / \mathrm{s}$ と固定した. 海 底摩擦係数 $K$ の值は, 海域に浅水方程式系を適用する計 算で用いられることの多い 0.0026 とした.

これらの方程式を白橋ら（2008）と同スキームの差分 法によって解く、入射境界では, 反射吸収造波による無 反射境界条件を導入し，反射波を領域外に透過させる. 


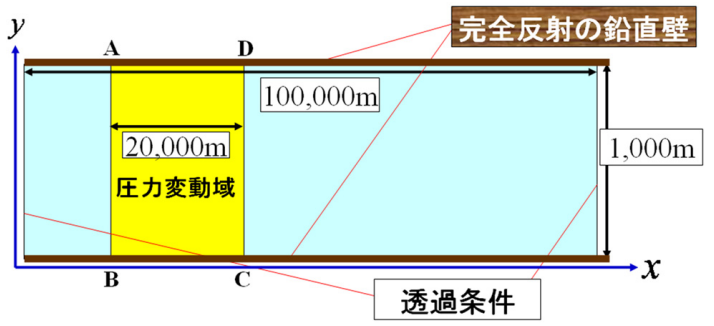

図-1 一様静水深のモデル地形の計算対象領域（気圧降下域 の幅は，無限長である. 辺 $\mathrm{AB} は, x=10,000 \mathrm{~m}$ にある.)

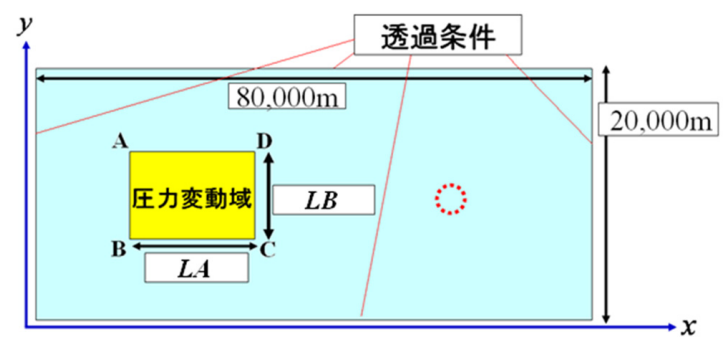

図-2 一様静水深のモデル地形の計算対象領域（気圧降下域 の幅は，有限長である。辺 $\mathrm{AB} は ， x=10,000 \mathrm{~m}$ にあり， その中点は, $y=10,000 \mathrm{~m}$ にある.)

また，実地形領域の海域内に設ける境界は，放射境界と する．他方，陸域境界では，完全反射条件を仮定する．

\section{3. 計算対象領域}

計算対象領域は，次の（a）及び（b）の2種類である.

（a）静水深が一様である平面形が長方形のモデル地形

（b）東シナ海の一部の領域

領域（a）は，図-1及び図-2に示すような，静水深 $h$ が 一様であり，平面形が長方形であるモデル地形である. 気圧変動に関する各パラメタが長周期波の生成に与える 影響を調べる際に，領域（a）を計算対象領域として用 いる．他方，領域（b）は，図-3に示す，東シナ海の東

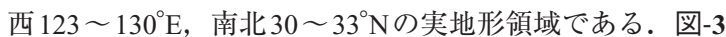
の破線 $(y=195,300 \mathrm{~m})$ に沿った水深分布は，図-4のよ うであり，䲡島列島の西に沖縄トラフが存在する.

\section{4. 気圧変動に関するパラメタ}

初期状態に打ける大気圧が，計算対象領域の全域にわ たって $0.0 \mathrm{~Pa}$ であると仮定する。この初期気圧を基準値 として, 気圧の変動を考える.

本研究では, 九州西岸域の湾におけるあびきを伴うよ うな長周期入射波の発生原因が，東シナ海海上における 気圧変動域の移動であると仮定する。しかしながら，現 時点では, 東シナ海の広範囲における気圧変動の詳細な 観測值が得られていない，そこで，数值解析では，気圧 変動に関する各パラメタの值を想定し，計算対象領域内 にある，長方形領域における海面上の気圧を時間ととも

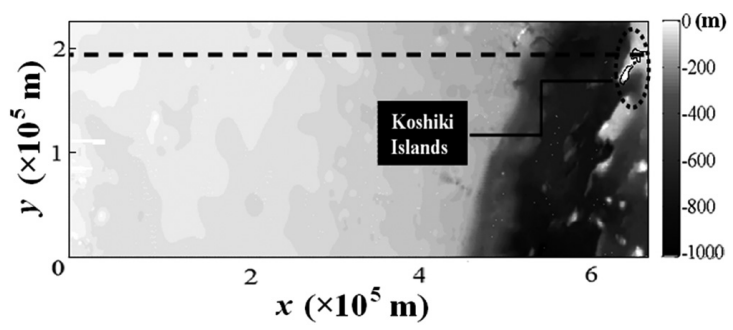

図-3 計算対象領域とする東西 $123 \sim 130^{\circ} \mathrm{E}$, 南北 $30 \sim 33^{\circ} \mathrm{N}$ の 東シナ海の水深（点線で囲った中に䲡島列島がある.）

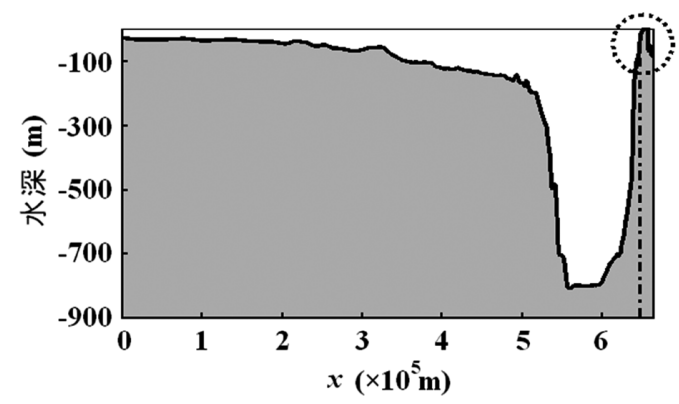

図-4 図-3の破線に沿った東シナ海の東西方向の水深分布

に変化させる，気圧が上昇，または，下降する地点が $x$ 軸の正の向き（東向き）に移動する速度を $u_{p}$, 各地点に おける気圧の変化速度を $w_{p}$, 圧力の最高值を $p_{\max }$, そし て，圧力の最低值を $p_{\text {min }}$ とする，例えば，気圧降下域が 図-2の $\mathrm{AB}\left(x=x_{1}\right)$ から $\mathrm{CD}$ まで移動する場合, 長方形 領域 $\mathrm{ABCD}$ 内の任意の地点での時刻 $t$ に打ける変動中の 圧力は, $p=w_{p}\left\{t-\left(x-x_{1}\right) / u_{p}\right\}$ となり, $0 \leq t<\left(x-x_{1}\right) / u_{p}$ で $p=$ $0, \quad\left(x-x_{1}\right) / u_{p}+p_{\min } / w_{p}<t$ で $p=p_{\min }$ であり, $\mathrm{ABCD}$ 外で絶え ず $p=0$ である.こうして, 各地点で $w_{p}$ の変化率で時間 的に気圧が変化するような気圧変動域が東向きに $u_{p}$ の速 度で移動するという，気圧変動域の移動状況が考慮され る. な抢, 大気と海水の相互干渉は, 無視する. 気圧変 動に関するパラメタとしては, これらの值の他に, 気 圧が変動する長方形領域の縦・横の長さと領域の位置 がある。

\section{5. 気圧変動の各パラメタに対する長周期波の依 存性}

（1）各地点における気圧の変化速度

計算対象領域を（a）の場合とする．計算格子間隔は, 東西・南北方向共に $\Delta x=\Delta y=100 \mathrm{~m}$ とし，また，計算時 間間隔を $\Delta t=0.5 \mathrm{~s}$ とする.

まず，計算対象領域を図-1のモデル地形とする．領域 の側方を完全反射の鉛直壁とし，前後を透過条件として，

一様静水深を $h=200 \mathrm{~m}$ とする.

パラメタのうち気圧変動点の移動速度を $u_{p}=\sqrt{g h}$, 気圧 の最低值を $p_{\min }=-1,000 \mathrm{~Pa}$ と固定し, 一方, 各地点の気圧 


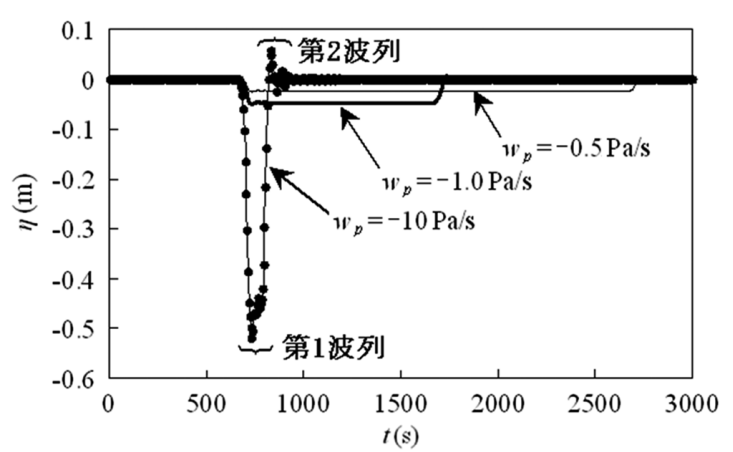

図-5 図-1 の計算対象領域中央地点における水面変動 $(h=$ $\left.200 \mathrm{~m}, u_{p}=\sqrt{g h}, p_{\min }=-1,000 \mathrm{~Pa}\right)$

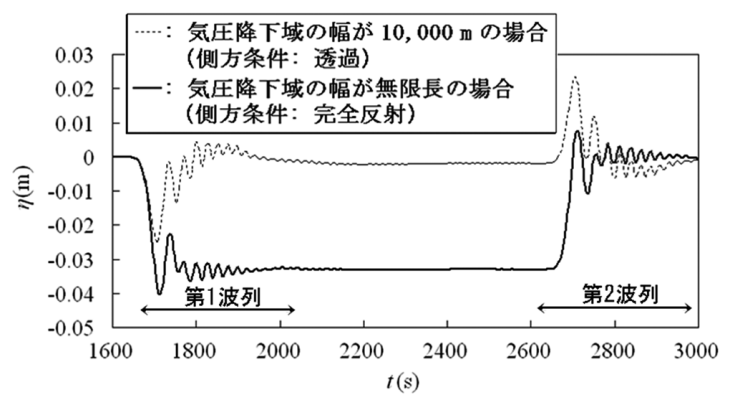

図-6 図-2の $x=60,000 \mathrm{~m}, y=10,000 \mathrm{~m}$ の地点における水面変 動 $\left(h=90 \mathrm{~m}, u_{p}=\sqrt{g h}, w_{p}=-1.0 \mathrm{~Pa} / \mathrm{s}, p_{\min }=-1,000 \mathrm{~Pa}\right)$

降下速度 $w_{p}$ を- $0.5,-1.0$, または， $-10.0 \mathrm{~Pa} / \mathrm{s}$ とする。図-1 の領域 $\mathrm{ABCD}$ 内を気圧降下域が移動するときの, 計算対 象領域中央地点に扔ける水面変動を図-5に示す.

これょり，二つの逆位相の波列からなる振動が発生す ることがわかる．このうち， $w_{p}=-10.0 \mathrm{~Pa} / \mathrm{s}$ のときの第 1 及び第 2 波列が図中で指示されている。気圧降下速度 $w_{p}$ の絶対值が大きいほど，第 1 波列の平均水位が大きく降 下し，また，より顕著な振動が発生する．従って，比較 的大きな振動が発生するためには，各地点における気圧 の変化速度の絶対值がある程度大きい必要がある。

\section{（2）気圧変動域の大きさ}

次に, 計算対象領域を図-2のモデル地形とする。領域 の側方及び前後を透過条件として，一様静水深を $h=$ $90 \mathrm{~m}$ とする.

気圧変動条件を $u_{p}=\sqrt{g h}, w_{p}=-1.0 \mathrm{~Pa} / \mathrm{s}$ 及び $p_{\min }=-1,000 \mathrm{~Pa}$ とする．図-2の領域 $\mathrm{ABCD}$ 内を気圧降下域が移動するとき の, $x=60,000 \mathrm{~m}, y=10,000 \mathrm{~m}$ の地点（図-2に描いた破線 円の中心位置) に打ける水面変動を図-6に示す。ここで, 領域 $\mathrm{ABCD}$ の辺の長さを $L A=L B=10,000 \mathrm{~m}$ としている.

なお，図-6には，気圧降下域の幅（ $y$ 方向長さ）を無 限長とした，他の条件が一致する場合の同地点における 水面変動も実線で描かれている。すなわち, 図-1のモデ ル地形のように，領域の側方を完全反射の鉛直壁とし， 前後を透過条件として, 一様静水深を $h=90 \mathrm{~m}$ とし,

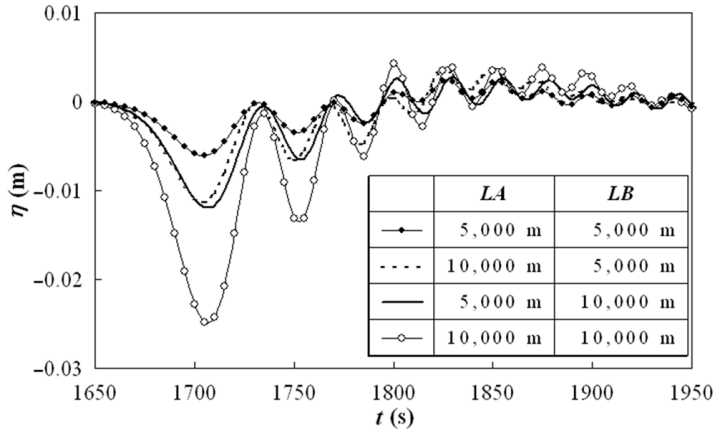

図-7 図-2の $x=60,000 \mathrm{~m}, y=10,000 \mathrm{~m}$ の地点における水面変動 $\left(h=90 \mathrm{~m}, \quad u_{p}=\sqrt{g h}, \quad w_{p}=-1.0 \mathrm{~Pa} / \mathrm{s}, \quad p_{\min }=-1,000 \mathrm{~Pa}\right)$

$L A=10,000 \mathrm{~m}, L B=20,000 \mathrm{~m}$ とした場合である.この場 合の数值解析は，気圧降下域の移動方向に沿った 1 次元 計算に相当する．気圧降下域の幅が非常に長いと，気圧 降下域内の吸い上げを補償するためにその前後から水が 多量に流出し，第1波列の水面変動の平均水位と，気圧 降下域の背後の水面が大きく下降する，ただし，図-6の 両者の場合の振動の周期は，等しくなっている.

また，気圧降下域が移動する，図-2の領域 $\mathrm{ABCD}$ の辺 の長さが異なる場合の $x=60,000 \mathrm{~m}, y=10,000 \mathrm{~m}$ の地点 に扮ける水面変動の第 1 波列を図-7に示す．長方形 $\mathrm{ABCD}$ の面積が最も広い場合と最も狭い場合とを比較す ると，前者は，その面積が4倍で，第 1 波列第 1 波の波高 が約 5.0 倍である。なお，これら4者の振動の周期は，ほ ぼ等しい。

\section{（3）気圧変動点の移動速度}

計算対象領域を図-2のモデル地形とし，領域の側方及 び前後を透過条件として，一様静水深を $h=90 \mathrm{~m}$ とする.

二つのパラメ夕 $w_{p}=-1.0 \mathrm{~Pa} / \mathrm{s}$ 及び $p_{\min }=-1,000 \mathrm{~Pa}$ を固定 し，気圧降下点の移動速度を $u_{p}=k \sqrt{g h}$ として，係数 $k$ $(k \geq 1.0)$ の值が異なる場合の $x=60,000 \mathrm{~m}, y=10,000 \mathrm{~m}$ の 地点に扔ける水面変動を図-8に示す。ここで， $L A=$ $L B=10,000 \mathrm{~m}$ としている.

これより, 気圧降下域の移動速度 $u_{p}\left(u_{p} \geq \sqrt{g h}\right)$ が大き いほど，周期 20〜 50s 程度の周期の振動が弱まり，水面 変動の最大波高が減少することがわかる，ただし，周期 200s 以上の長周期の波は， $u_{p}$ が大きくても発生し，その 周期は， $u_{p}\left(u_{p} \geq \sqrt{g h}\right)$ が大きいほど長い. $k=2.5$ の場合, 最大波高及び長周期の波の周期は，それぞれ， $k=1.0$ の 場合の約 0.25 及び 1.5 倍である.

\section{（4）気圧降下域の移動と気圧上昇域の移動の違い}

計算対象領域を図-2のモデル地形とする。一様静水深 を $h=90 \mathrm{~m}$ とし， $u_{p}=\sqrt{g h}$ とする. 図-2の領域 $\mathrm{ABCD}$ 内を気 圧降下域が移動する場合 $\left(w_{p}=-1.0 \mathrm{~Pa} / \mathrm{s}, p_{\min }=-1,000 \mathrm{~Pa}\right)$ と, 気圧上昇域が移動する場合 $\left(w_{p}=1.0 \mathrm{~Pa} / \mathrm{s}, p_{\text {min }}=\right.$ 1,000Pa）の, $x=60,000 \mathrm{~m}, y=10,000 \mathrm{~m}$ の地点における 


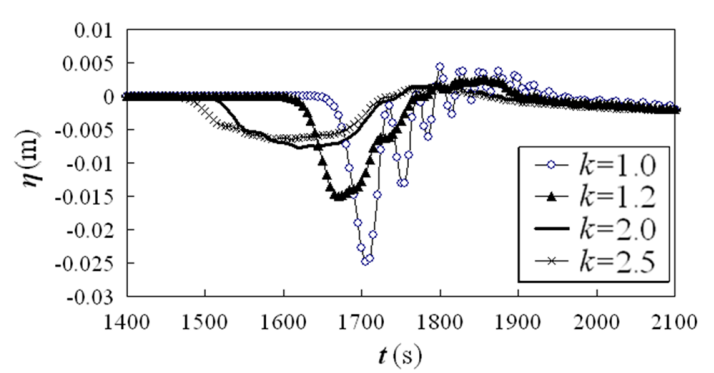

図-8 図-2 の $x=60,000 \mathrm{~m}, y=10,000 \mathrm{~m}$ の地点における水面変 動 $\left(h=90 \mathrm{~m}, L A=L B=10,000 \mathrm{~m}, u_{p}=k \sqrt{g h}, w_{p}=-1.0 \mathrm{~Pa} / \mathrm{s}\right.$, $p_{\text {min }}=-1,000 \mathrm{~Pa}$ )

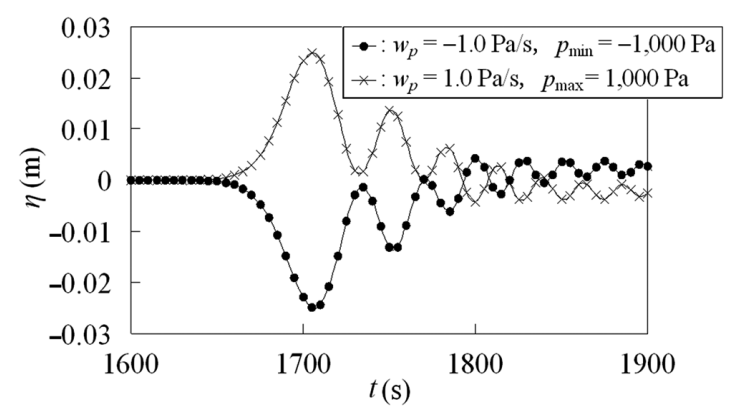

図-9 図-2の $x=60,000 \mathrm{~m}, y=10,000 \mathrm{~m}$ の地点における水面変 動 $\left(h=90 \mathrm{~m}, L A=L B=10,000 \mathrm{~m}, u_{p}=\sqrt{g h}\right)$

水面変動を図-9に示す。ここで， $L A=L B=10,000 \mathrm{~m}$ とし ている. 両者が逆位相の振動であることがわかる.

\section{6. 気圧降下後の気圧上昇（気圧回復）による効果}

計算対象領域を（a）の場合として，気圧降下後に気 圧が上昇して回復する場合に発生する長周期波を調べる.

図-2の領域 $\mathrm{ABCD}$ 内の各地点において, 気圧が降下し, 気圧が最低值 $p_{\min }=-1,000 \mathrm{~Pa}$ となった時刻から時間 $\Delta t$ 後 に気圧が上昇し始め, 初期気圧 $0.0 \mathrm{~Pa}$ に回復する場合の, $x=60,000 \mathrm{~m}, y=10,000 \mathrm{~m}$ の地点における水面変動を図-10 に示す.ここで, 一様静水深を $h=90 \mathrm{~m}$ とし, 気圧の降 下及び上昇地点の移動速度を $u_{p}=\sqrt{g h}$ として, 気圧の降下 及び上昇速度 $w_{p}$ をそれぞれ -1.0 及び $1.0 \mathrm{~Pa} / \mathrm{s}$ としている. また， $L A=L B=10,000 \mathrm{~m}$ である。

気圧が上昇する場合は, 降下する場合と逆位相の振動 が発生するが， $\Delta t=0 \mathrm{~s}$ のき，気圧の降下により生成さ れた第 2 波列に, 気圧の上昇に伴う第 1 波列が重なり, この場合, 水面変動の波高が, 気圧の回復がないときの 約 2.5 倍となる.

\section{7. 東シナ海における長周期波の発生}

計算対象領域を（b）の場合，すなわち，東シナ海の 図-3に示す領域として，想定する気圧変動域の移動によ って東シナ海でどのような長周期波が発生して伝播する のかを調べる．計算格子間隔は，東西方向に $\Delta x=750 \mathrm{~m}$,

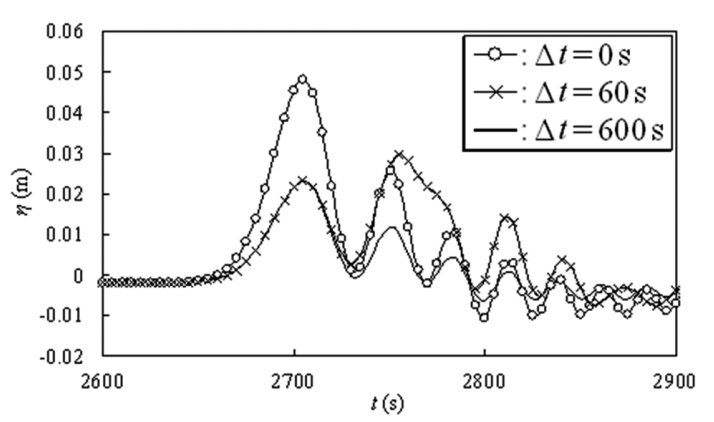

図-10 各地点の気圧降下完了時から $\Delta t$ 後に気圧が上昇し始め る場合の図-2の $x=60,000 \mathrm{~m}, y=10,000 \mathrm{~m}$ に打ける水面 変動 $\left(h=90 \mathrm{~m}, L A=L B=10,000 \mathrm{~m}, u_{p}=\sqrt{g h}, w_{p}=\right.$ $0.1 \pm \mathrm{Pa} / \mathrm{s}, \quad p_{\min }=-1,000 \mathrm{~Pa}$ )

南北方向に $\Delta y=900 \mathrm{~m}$ とし，また，計算時間間隔を $\Delta t=$ $0.5 \mathrm{~s}$ とする.

1979年3月 31 日に女島で測定された気圧変化を考慮し て, 最低気圧を $p_{\min }=-500 \mathrm{~Pa}$ とし, 各地点における気圧 の降下速度を $w_{p}=-1.0 \mathrm{~Pa} / \mathrm{s}$ とする. 気圧降下域が東向き に移動すると仮定し，その速度を $u_{p}=\sqrt{g h}$ とする．ここで， $h$ は，図-3の $200,000 \mathrm{~m}<x<450,000 \mathrm{~m}$ の領域におけるお およその平均静水深である $90 \mathrm{~m}$ に設定する. また, 気圧 降下域が移動する領域は, 東西方向 $225,000 \mathrm{~m} \leqq x \leqq$ $450,000 \mathrm{~m}$, 南北方向 $117,000 \leqq \mathrm{y} \leqq 207,000 \mathrm{~m}$ の領域とす る.このような計算条件を設定したときの水位分布の時 間変化を図-11に示す. 気圧変動地点の東端より, 水面 波が弧を描くように伝播していく.

図-4に一点鎖線で示した $x=648,750 \mathrm{~m}, y=195,300 \mathrm{~m}$ の地点における水面変動を図-12に示す。この地点は, 上甑島浦内湾の湾口沖に位置している. 気圧降下に伴い, 水面に, ある周期の振動が発生し, 上齀島付近まで伝播 している。長周期波の波高は，上潧島に近付くにつれ， 浅水変形によって増大する。この地点に伝播した長周期 波の平均周期は，約 820sである。これは，柿沼ら（2009） の数值解析及び現地観測より得られる，2本に分岐した 湾形を有する浦内湾の, 湾奥に小島漁港がある側の湾の 湾水振動の第 2 モードの周期約 720s, または, 両湾奥間 の湖水振動の第 1 モードの周期約 $600 \mathrm{~s}$ に比較的近い. 白 橋ら（2008）の解析手法を適用すると, 周期 $820 \mathrm{~s}$ の波の 入射により，入射波波高の約 2.5 倍の増幅が小島漁港で 現れることがわかる. 序論で述べた 2009 年 2 月 24 日〜26 日には，熊本県で $720 \mathrm{~s}$ 程度の周期の振動が観測されてお り（長崎海洋気象台ら，2009），こうした長周期波は， 気圧変動域の移動により生成される可能性がある.

また, 気圧降下域の移動速度 $u_{p}$ のみを変え, $u_{p}=2.5 \sqrt{g h}$, $h=90 \mathrm{~m}, w_{p}=-1.0 \mathrm{~Pa} / \mathrm{s}$ 及び $p_{\min }=-500 \mathrm{~Pa}$, とした場合の, 同地点に打ける水面変動を図-13に示す。気圧降下域の 移動速度 $u_{p}$ が 2.5 倍になると，図-8に示したように，振幅 

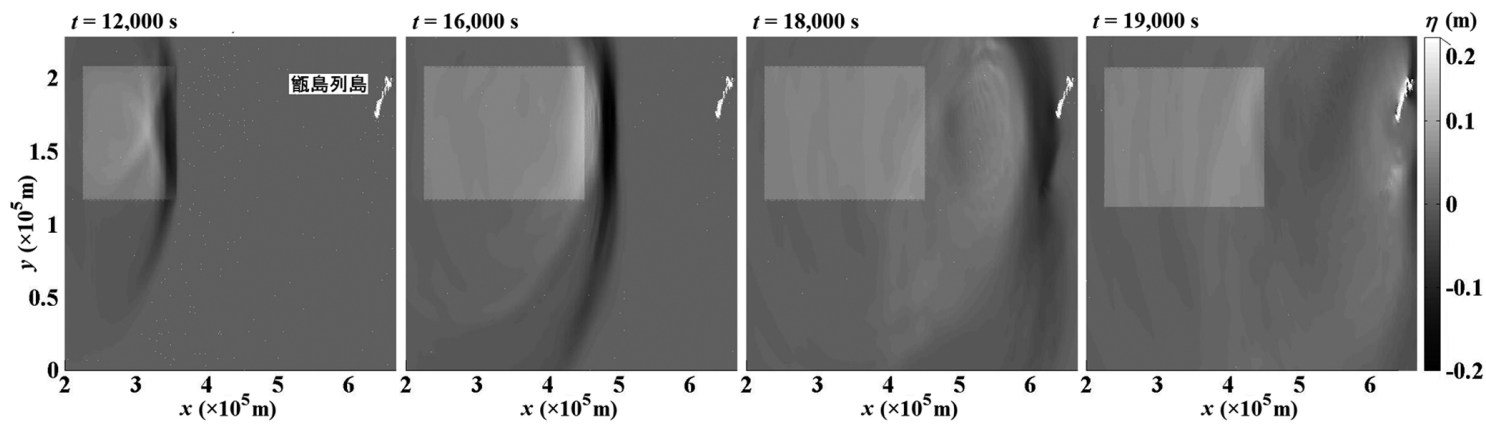

図-11 水位分布の時間変化 $\left(u_{p}=\sqrt{g h}, h=90 \mathrm{~m}, w_{p}=-1.0 \mathrm{~Pa} / \mathrm{s}, p_{\min }=-500 \mathrm{~Pa}\right)$

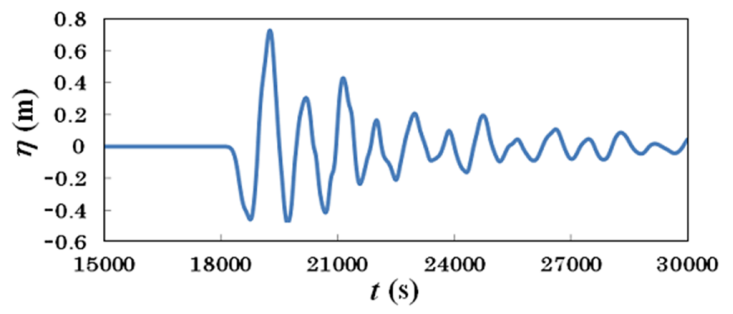

図-12 図-3の $x=648,750 \mathrm{~m}, y=195,300 \mathrm{~m}$ の地点における水面 変動 $\left(u_{p}=\sqrt{g h}, h=90 \mathrm{~m}, w_{p}=-1.0 \mathrm{~Pa} / \mathrm{s}, p_{\min }=-500 \mathrm{~Pa}\right)$

が大きくならず，また，長周期波の周期が長くなる。こ の地点に伝播した長周期波の平均周期は, 約 1,470 sであ り，図-12の場合の2倍弱である。同様にして，これは， 浦内湾の両分岐湾の第 1 モードの固有周期約 1,620 s に比 較的近く，周期 $1,470 \mathrm{~s}$ の波の入射により，入射波波高の 約3.0倍の増幅が小島漁港で現れることがわかる.

\section{8. 結論}

海洋上の長方形領域で気圧変動域が移動すると仮定 し，海面に打ける気圧を考慮した非線形浅水方程式系に 基づく数值モデルを適用して, 長周期波発生過程の数值 解析を行なった。気圧降下域の幅が非常に長いと，第 1 波列の変動の中心が大きく降下すること, 気圧降下域の 移動速度が長周期波の波速と比べて大きいほど，波高が 減少し，短周期の振動が消え，長周期の波の周期が長く なること, 気圧降下速度が大きいほど顕著な振動が見ら れることがわかった．また，気圧降下域の移動後に気圧 上昇域が移動する場合，各地点で，気圧降下後，直ちに 気圧が上昇し始めると，比較的大きな振動が発生する.

東シナ海上の気圧変動域の移動に伴い生成した長周期 波の波列は, 䲡島列島付近まで伝播し, 浅水変形により 波高が増大する．気圧変動域の東向きの移動速度が長周 期波の波速よりも大きいと，長周期波の波高が低減し，

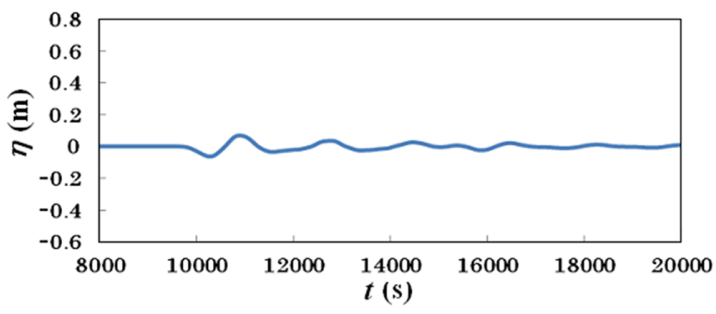

図-13 図-3の $x=648,750 \mathrm{~m}, y=195,300 \mathrm{~m}$ の地点における水面 変動 $\left(u_{p}=2.5 \sqrt{g h}, h=90 \mathrm{~m}, w_{p}=-1.0 \mathrm{~Pa} / \mathrm{s}, p_{\min }=-500 \mathrm{~Pa}\right)$

周期が長くなる，女島で過去に観測された気圧変化を考 慮して，気圧変動に関するパラメタを想定したところ， 上㽀島浦内湾の小島漁港側の湾水振動の第 2 モード，ま たは，湖水振動の第 1 モードの周期に比較的近い長周期 波が発生することが確認された.

今後, 気圧変動とつり合っていた海水の位置エネルギ 一が, 気圧の回復過程でどのように長周期波のエネルギ 一に転じるかに関して検討する必要がある。そして，あ びき発生時の気圧変動について観測值に基づいた調查を 進め, その成果を取り入れた数值解析を行ない, 東シナ 海における気圧変動と水面変動の関係をより詳細に調 べ，あびき予測の実現化を目指したい。

\section{参考文 献}

柿沼太郎 - 浅野敏之 - 井上太介 - 山城 徹 - 安田健二 （2009）：上㥢島浦内湾における2009年 2 月潮位副振動の 被害調查, 海岸工学論文集, 第56巻, pp. 1391-1395.

白橋朋大・柿沼太郎・浅野敏之・佐藤道郎 (2008)：甑島の分 岐した湾で発生する長周期水位変動の数值解析，海岸工 学論文集, 第 55 巻, pp. 216-220.

長崎海洋気象台・鹿児島地方気象台・熊本地方気象台 (2009)：平成 21 年 2 月 24 日からの潮位の副振動, 災害時 気像資料, $13 p$.

Hibiya, T. and K. Kajiura (1982): Origin of the abiki phenomenon (a kind of seiche) in Nagasaki Bay, J. Oceanogr. Soc. Japan, Vol. 38, pp. 172-182. 